\title{
Quality control in colon and rectal cancer surgery
}

\author{
Karl-Heinrich Link \\ From 16th International Charles Heidelberger Symposium on Cancer Research \\ Coimbra, Portugal. 26-28 September 2010
}

The perioperative and long term results of colon and rectal cancer surgery are varying to significant extents. Our working group has analyzed the potential reasons for those variations. Quality depends on the surgeon's training and on the hospital structures. We have decided on eight points which should be provided by the hospital/ surgeon to warrant the optimal quality of treatment $[1,2]$.

Published: 24 September 2010

\section{References}

1. Link KH, Kornmann M, Bittner R, Kockerling F, Arbogast R, Gastinger I, Heitland W, Henne-Bruns D, Lang H, Lippert H, Mann M, Meyer HJ, Polonius MJ, Post S, Raab R, Schiedeck T, Schumpelick V, Kornmann M: Quality criteria for treatment of colorectal cancer - From a surgeon's viewpoint. Chirurg 2010, 81:222-230.

2. Link KH, Kornmann M, Mann M, Bittner R: Multimodal Treatment of Colon and Rectal Cancers: Quality Parameters. Viszeralmedizin 2009, 25:105-117.

- Convenient online submission

- Thorough peer review

- No space constraints or color figure charges

- Immediate publication on acceptance

- Inclusion in PubMed, CAS, Scopus and Google Scholar

- Research which is freely available for redistribution 